\title{
Otta seal - the new way to solve problems of maintenance of gravel roads in Lithuania
}

\author{
Judita Gražulytėe, Daiva Žilionienè ${ }^{\mathrm{b}}$, Faustina Tuminienè $\dot{\mathrm{c}}^{\mathrm{c}}$ \\ ${ }^{a, c}$ Road Research Institute, Vilnius Gediminas Technical University, Linkmenu str. 28, LT-08217 Vilnius, Lithuania \\ ${ }^{b}$ Dept of Roads, Vilnius Gediminas Technical University, Sauletekio al. 11, LT-10223 Vilnius, Lithuania
}

\begin{abstract}
About $34.2 \%$ of unbound Lithuanian granular roads, which need to be sealed, are with low traffic volume. The cost of maintenance, loss of time, social discomfort and other problems of travelling on gravel roads bring financial failure annually. Usually, problems of this kind are solving by paving asphalt, but in practice it is very expensive and causes problems of safety road. As the result, the most effective solution for gravel roads by aspects of cost and performance is Otta seal. This paper aims to illustrate the behaviour of Otta seal at traffic and climatic conditions of Lithuania. The experimental research has been done for 26 sections of gravel roads, which were surfaced with the double Otta seal by rehabilitation. There are analysed characteristics of materials and one year' performance of the double Otta seal in all objects of investigation and based on the results of this research, there are made conclusions.
\end{abstract}

Keywords: double Otta seal; soft (low viscosity) bitumen; aggregates; visual assessment; gravel road; low-volume road.

\section{Introduction}

Low-volume (gravel) roads play an important role in the transport infrastructure. They connect low-populated and isolated areas into a single transport system. Unfortunately, gravel road maintenance requires major budgetary resources. In order to reduce the number of gravel roads, 2002-2015 National Road Maintenance and Development Programme of the Republic of Lithuania (hereafter Programme) was initiated. The Programme aim is to reduce the number of gravel roads in the Lithuanian State Road Network to $32 \%$ by 2015.

According to Lithuanian Road Administration data, gravel roads make up 34.2\% of the Lithuanian State Road Network in 2013. Gravel roads effect ride quality, vehicle delay costs, fuel consumption, and maintenance costs, and have a negative environmental impact.

Paving gravel roads improves driving conditions, but the average driving speed of traffic flow does not meet the existing horizontal alignment curve radius. Therefore the popular opinion is that the design solution to improve the condition of the gravel road network by paving is too expensive [1], [2]. Based on low traffic volume (Annual Average Daily Traffic $($ AADT $)<1000$ vehicles per day (vpd)) a more economical and reasonable method is to apply the surface dressing to the gravel road.

Bituminous surfacing is an integral component of paved roads. It performs a number of functions that offer many advantages over unsealed roads. These include [3]:

- provision of a durable, impervious surfacing which seals and protects the pavement layers from moisture ingress and consequent loss of pavement strength and degradation;

- provision of a skid-resistance surface which can resist the abrasive and disruptive forces of traffic and the environment;

- prevention of gravel loss, resulting in elimination of costs of replacing gravel, a finite non-renewable resource;

- prevention of the formation of corrugations, dust and mud which generally permits relatively safe travel at high speeds and lower vehicle operating and maintenance costs.

As for all bituminised roads, the pavement strength must be adequate to carry the anticipated traffic load [3]. One type of surfacing that can provide an economic and practical alternative to traditional surfacings is the Otta seal [4], [5]. The main advantages of the Otta seal over other types of bituminous surfacings include [4], [5]:

Corresponding author: Judita Gražulytė. E-mail address: judita.grazulyte@vgtu.lt

http://dx.doi.org/10.3846/enviro.2014.152

(C) 2014 The Authors. Published by VGTU Press. This is an open-access article distributed under the terms of the Creative Commons Attribution License, which permits unrestricted use, distribution, and reproduction in any medium, provided the original author and source are credited. 
- an ability to tolerate the use of relatively inferior aggregates, such as screened gravel, rather than crushed rock, without impairment of the performance of the surfacing;

- an enhanced durability that is better able to combat high solar radiation that causes rapid ageing and hardening of the binder and consequent degradation of the surfacing;

- scope for utilising labour-based methods in many aspects of its construction;

- a favourable life-cycle cost-benefit ratio of the order of $50 \%$ to $60 \%$ of the more commonly used seals, such as the Chip seal.

The Otta seal design solution does not add strength to the existing gravel surface, but this type of the surface dressing improves the gravel road operational characteristics.

\section{Use the Otta seal surfacing}

Natural gravel materials have traditionally been used for upgrading earth to gravel roads or for re-gravelling existing gravel roads. However, serious concerns have arisen regarding the continuous use of vast amounts of gravel - a non-renewable, finite resource - which is not only being rapidly depleted in many countries but is also unsustainable in the medium to long term. This has prompted road engineers to consider the use of low-cost bituminous surface treatments on these gravel roads as an alternative to re-gravelling them in an unsustainable and increasingly costly programme [4], [5].

The use of the Otta seal extends to a number of developing countries, particularly in eastern and southern Africa, where its use is becoming more wide-spread as more experience is gained in its design, construction and maintenance [4], [5]. The Otta seal was constructed in Norway, Sweden, Finland, Island, USA (Minnesota), Bangladesh, Australia and in a number of eastern and southern Africa countries as an alternative to paving gravel roads.

The Otta seal is a particular type of bituminous surface treatment which was originally developed by the Norwegian Road Research Laboratory (NRRL) in the early 1960s [4], [5]. The design of the Otta seal is relatively simple. It relies on an empirical approach that is based on experience in the selection of both an appropriate type of binder and an aggregate application rate [4-5].

According Overby and Pinard the choice of a particular type of Otta seal in relation to traffic level is broadly [4], [5]. It is recommended to use the single Otta seal with sand cover seal when the AADT $<500$ vpd and the double Otta seal when the AADT $>500 \mathrm{vpd}$.

One of the main advantages of an Otta seal is the flexibility it offers in terms of the variety of materials that can be used for producing the graded aggregate [6]. Both crushed or uncrushed material and a mixture of both can be used for producing graded aggregate for Otta seals [3], [5]:

- crushed rock: e.g. Gabbro, Basalt, Silcrete, Sandstone;

- screened/crushed gravel: e.g. Moraine, Coral Stone, Volcanic Ash, Laterite, decomposed Granite, decomposed Basalt;

- river and lake gravels.

The type of binder used in an Otta seal significantly affects its constructability, durability and ultimate performance. It is therefore critically important that a correct choice of binder is made to ensure that the critical function of a complete coating of the mineral aggregate particles, even the fines, is achieved during construction [4].

During construction of an Otta seal, the following points should be noted [4], [5]:

the aggregates should preferably be applied by self-propelled or truck mounted chip spreaders. However, it is also feasible to spread the aggregate by hand using labour, both from a reversing truck or from staggered aggregate stockpiles along the road side [7], [8].

- the use of pneumatic tyre rollers (minimum weight 12 tons) is essential in view of their ability to knead the binder upwards through the aggregate particle interstices. The more intensive the rolling that is applied to the aggregate the better will be the quality of the Otta seal. In the absence of pneumatic rollers, compaction can be successfully carried out by the use of loaded trucks following a set rolling pattern covering the entire surfaced area.

- the road should be opened to traffic immediately after rolling is completed as this will assist in the further compaction of the seal. In order to avoid whip off of the aggregate during the first few weeks after opening the road to traffic, a maximum speed limit of 40-50 km/hour should be observed.

- the initial occurrence of fatty spots should not be cause for concern and can be rectified by blinding with fine aggregate which is rolled into the bitumen.

- a minimum period of 8-12 weeks should elapse between the construction of the first and the second layers.

\section{Experimental research of the double Otta seal in Lithuania}

Based on the practical experience on the double Otta seal in Nordic (Norway, Sweden, Finland and Island) countries and to clarify the effectiveness of this type of the surface dressing under Lithuanian conditions, 26 experimental sections $(22.94 \mathrm{~km})$ with the double Otta seal were performed in 2012 . Under the maximum AADT (vpd), calculated maximum design load A (in millions), the number of the freeze-thaw cycles and the depth of the frozen ground these sections were selected from the five Lithuanian regions, i.e. Klaipėda-Tauragè -6 sections, Šiauliai-Telšiai -5 sections, PanevėžysUtena -6 sections, Vilnius-Alytus - 4 sections and Kaunas-Marijampole -5 sections (Table 1). 
Table 1. Double Otta seal experimental road sections and their traffic characteristics

\begin{tabular}{|c|c|c|c|c|c|c|}
\hline No. & Road No. & Road name & Road section, $\mathrm{km}$ & $\begin{array}{l}A A D T, \\
\text { vpd }\end{array}$ & $A A D T_{H V}, \%$ & $\begin{array}{l}\text { Maximum } \\
\text { design load } A \text {, } \\
\text { millions }\end{array}$ \\
\hline \multicolumn{7}{|c|}{ Klaipėda-Tauragè region } \\
\hline 1 & 1708 & Padubysys-Vosbutai-Butkišké-Putriai & $9.70-10.35$ & 76 & 13.16 & 20237 \\
\hline 2 & 1717 & Armeniškiai-Aukštvilkiai & $9.19-9.30$ & 231 & 9.09 & 36182 \\
\hline 3 & 3702 & Kaukolikai-Nausédai-Raudoniai & $8.92-9.40$ & 76 & 6.58 & 9812 \\
\hline 4 & 4215 & Juknaičiai-Tatamiškiai & $6.40-7.20$ & 157 & 10.83 & 79109 \\
\hline 5 & $4516(1)$ & Skaudvilè-Bijotai-kelias Kaltinènai-Kražiai & $9.95-10.90$ & 120 & 8.33 & 7972 \\
\hline 6 & $4516(2)$ & Skaudvilè-Bijotai-kelias Kaltinènai-Kražiai & $10.90-11.53$ & 54 & 7.41 & 19011 \\
\hline \multicolumn{7}{|c|}{ Šiauliai-Telšiai region } \\
\hline 7 & 1018 & Papilè-Draginiai-Žarẻnai-Dauginčiai & $5.30-5.83$ & 105 & 0.95 & 613 \\
\hline 8 & 2707 & Žiogaičiai-Purvènai & $0.00-0.60$ & 148 & 3.38 & 4906 \\
\hline 9 & 2735 & Tirkšliai-Lèteniai & $2.00-2.62$ & 137 & 9.49 & 34955 \\
\hline 10 & 3208 & Rietavas -Lioliai-Mažieji Mostaičiai & $17.75-19.48$ & 453 & 44.15 & 680090 \\
\hline 11 & 4118 & Laukuva-Vaitkaičiai-kelias Rietavas-Tverai-Varniai & $9.30-10.00$ & 183 & 4.92 & 23303 \\
\hline \multicolumn{7}{|c|}{ Panevėžys-Utena region } \\
\hline 12 & 1235 & Kurtiniai-Aušra & $0.80-2.12$ & 138 & 10.87 & 53966 \\
\hline 13 & 1401 & Dūkštas-Rimšè-Pūškos-Meikštai-Kačergiškè & $25.40-26.15$ & 134 & 10.45 & 32502 \\
\hline 14 & 2427 & Salamiestis-Stuburiai & $1.70-3.10$ & 100 & 10.00 & 32502 \\
\hline 15 & $2816(1)$ & Inturkè-Ketuoja-Lakaja & $0.00-0.40$ & 173 & 2.89 & 10425 \\
\hline 16 & $2816(2)$ & Inturkè-Ketuoja-Lakaja & $2.20-4.24$ & 173 & 2.89 & 10245 \\
\hline 17 & 3610 & Lukšiai-Kalbutiškis-Dusetos & $2.97-3.63$ & 133 & 9.02 & 44767 \\
\hline \multicolumn{7}{|c|}{ Vilnius-Alytus region } \\
\hline 18 & 3918 & Jašiūnai-Keidžiai & $3.43-4.03$ & 190 & 6.84 & 42927 \\
\hline 19 & 4404 & Pabradė-Prienai-Kiemeliškès & $15.64-16.17$ & 231 & 2.60 & 4906 \\
\hline 20 & 4726 & Grendavè-Gruožninkai & $0.00-1.05$ & 278 & 9.71 & 131848 \\
\hline 21 & 5017 & Noškūnai-Panočiai & $7.52-8.38$ & 205 & 20.49 & 137980 \\
\hline \multicolumn{7}{|c|}{ Kaunas-Marijampolè region } \\
\hline 22 & 2623 & Mockai-Senoji Radiškè-Kalniai & $2.60-3.58$ & 114 & 21.05 & 106705 \\
\hline 23 & 2635 & Sasnava-Barsukinè & $2.20-3.40$ & 194 & 5.15 & 9812 \\
\hline 24 & 2642 & Mikoliškiai-Jakimavičiai & $0.00-0.95$ & 95 & 5.26 & 4293 \\
\hline 25 & 3539 & $\begin{array}{l}\text { Privažiuojamasis kelias prie Piktaičių nuo kelio } \\
\text { Raseiniai-Tytuvènai-Radviliškis }\end{array}$ & $0.00-1.40$ & 137 & 8.96 & 82175 \\
\hline 26 & 5123 & Gižai-Balsupiai & $2.50-3.50$ & 85 & 14.12 & 40474 \\
\hline
\end{tabular}

The Double Otta seal was applied on the new 7-10 cm base course from decomposed granite. The existing gravel road $(\geq 30 \mathrm{~cm})$ was matched up to the frost blanket course if an existing gravel road met to the requirements of frost blanket course (Fig. 1).

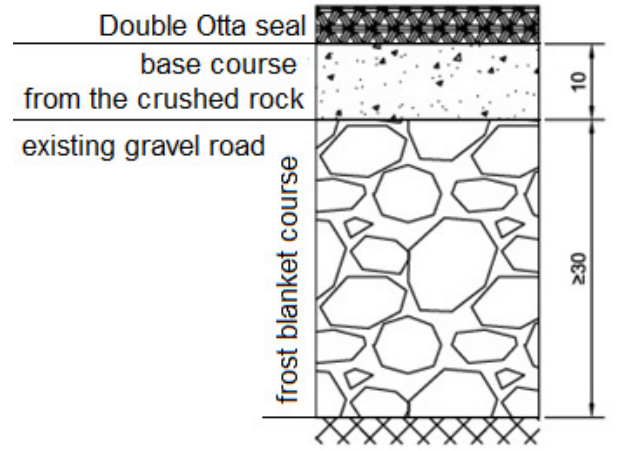

Fig. 1. Principle structure of the double Otta seal, constructed on a base course from decomposed granite 
Bitumen emulsion, which met the Lithuanian standards LST EN 12591 Bitumen and Bituminous Binders - Specifications for Paving Grade Bitumen, and TRA BITUMAS 08 List of Technical Requirements for Bituminous and Polymer Modified Bitumen Used for Roads was used for the double Otta seal. It was produced from the soft bituminous V 3000 or V 6000 (probative technically) and applying $60 \%$ of the nominal content of binder. The amount of the spread binder was $1.8 \mathrm{~kg} / \mathrm{m}^{2}$ of V 3000 made of soft bitumen and $2.0 \mathrm{~kg} / \mathrm{m}^{2}-\mathrm{V} 6000$, respectively.

For the double Otta seal the aggregate of these characteristics, i.e. $0 / 16$ fraction, $S Z_{18} \leq 18 \%$ (the resistance for fragmentation according the impact resistance value) and $L A_{20} \leq 20 \%$ (Los Angeles coefficient), was used. The grain size distribution for the aggregate is shown in Fig. 2. The amount $\left(14 \mathrm{l} / \mathrm{m}^{2}\right)$ of the spread aggregate could be adjusted according to the spread test results. Adhesive additives were not used.

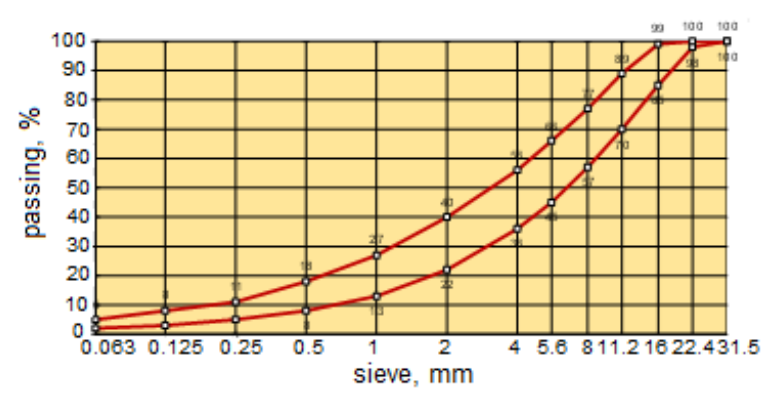

Fig. 2. Gradation curves for the double Otta seal aggregate

Research of the double Otta seal sections included:

- tests and evaluation of the grain size distribution of the aggregate, used for the double Otta seal and base course;

- tests and evaluation of the properties of the binder, used in the double Otta seal;

- tests and evaluation of a base course bearing capacity according to the deformation module $E_{v_{2}}$ and the compaction coefficient $E_{v_{1}} / E_{v_{2}}$ (according to Lithuanian standard LST 1360.5 Soils for Road Construction. Testing Methods. Plate Load Test);

- tests and evaluation of the double Otta seal roughness (IRI, m/km) in autumn 2012 by the Road Surface Profilometer Dynatest 5051 RSP and in summer 2013 by the Mobile Road Survey Laboratory RST 28;

- the qualitative visual assessment of defects in different seasons (autumn 2012, spring 2013, and autumn 2012).

The qualitative visual assessment of defects was done according to the new methodology of the Qualitative Visual Assessment of the Double Otta Seal Defects. This methodology was created based on the Lithuanian standards LST EN 12272-2 Surface Dressing - Test Methods - Part 2: Visual Assessment of Defects and LST EN 12274-7:2005 Slurry Surfacing - Test Methods - Part 8: Visual Assessment of Defects. All defects of the double Otta seal were grouped:

- $P_{1}$ - fatting up, bleeding and tracking in \%;

- $P_{2}-$ scabbing, tearing and longitudinal joint crack in $\%$;

- $P_{3}$ - corrugation and blister in \%;

- $P_{4}$ - streaking in meters.

The groups of defects were evaluated and results were summarized. All results show the effect of the double Otta seal in specific Lithuanian traffic and climatic conditions.

\section{Analysis of the experimental research results}

Based on the experimental research results (quantification of different size aggregate particles) it was found that not all the test road section aggregates satisfied the required gradation curves. However, in the all test road sections (except the road $\mathrm{Nr} .1018$ ) the amount of the particle size $<0.063 \mathrm{~mm}$ in the base course aggregate mixtures satisfied the required gradation curves, i.e. the amount was $0-7 \%$.

Three types of the bitumen emulsions for the double Otta seal were used (Table 2). Based on the analysis of the test results of the base course bearing capacity (by the deformation module $E_{v_{2}}$ and the compaction coefficient $E_{v_{1}} / E_{v_{2}}$ ) it was determined that the required deformation module $\left(E_{v_{2}} \geq 100 \mathrm{MPa}\right)$ of the base course from decomposed granite does not meet the requirement on three test road sections: the road No. $1401 \mathrm{Pk} 256+33$ (road left side, measured in July, 2012) and Pk 258+72 (road left side, measured in August, 2012), the road No. 2816(2) Pk 22+40 (road left side, measured in August, 2012) and the road No. $2642 \mathrm{Pk} 6+00$ (road right side, measured in August, 2012).

Results of the qualitative visual assessment of the double Otta seal road sections are shown in Fig. 3 . There found that the most significant defects were of $P_{1}$ group (fatting up, bleeding and tracking). Very few defects were found in 2013 autumn in comparison with results in 2013 spring and in 2012 autumn of $P_{2}$ group (scabbing, tearing and longitudinal joint crack). There were less $P_{3}$ group defects (corrugation and blister) than were found in comparison with defects of other groups $\left(P_{1}\right.$, $P_{2}$ and $\left.P_{4}\right)$. The streaking $\left(P_{4}\right.$ group defect) was found in 4 of the 26 road sections, i.e. $145.00 \mathrm{~m}-$ the road No. 472 and 
$20.00 \mathrm{~m}$ - the road No. 4404 in Vilnius-Alytus region, $5.00 \mathrm{~m}$ - the road No. 3208 and $156.00 \mathrm{~m}-$ the road No. 2735 in Šiauliai-Telšiai region.

Table 2. Characteristics of bitumen emulsions used for the double Otta seal

\begin{tabular}{llll}
\hline Bitumen emulsion & Amount of binder, \% & Kinematic viscosity, $\mathrm{mm}^{2} / \mathrm{s}$ & Cohesive ability, \% \\
\hline C60B1PA-V6000 & $58.9-62.3$ & $4802-13520$ & $80-100$ \\
C60BF1-PA & $55.7-75.0$ & $4153-12708$ & $30-80$ \\
EKL 66-6000 & $65.4-66.4$ & $9261-11910$ & $85-100$ \\
\hline
\end{tabular}
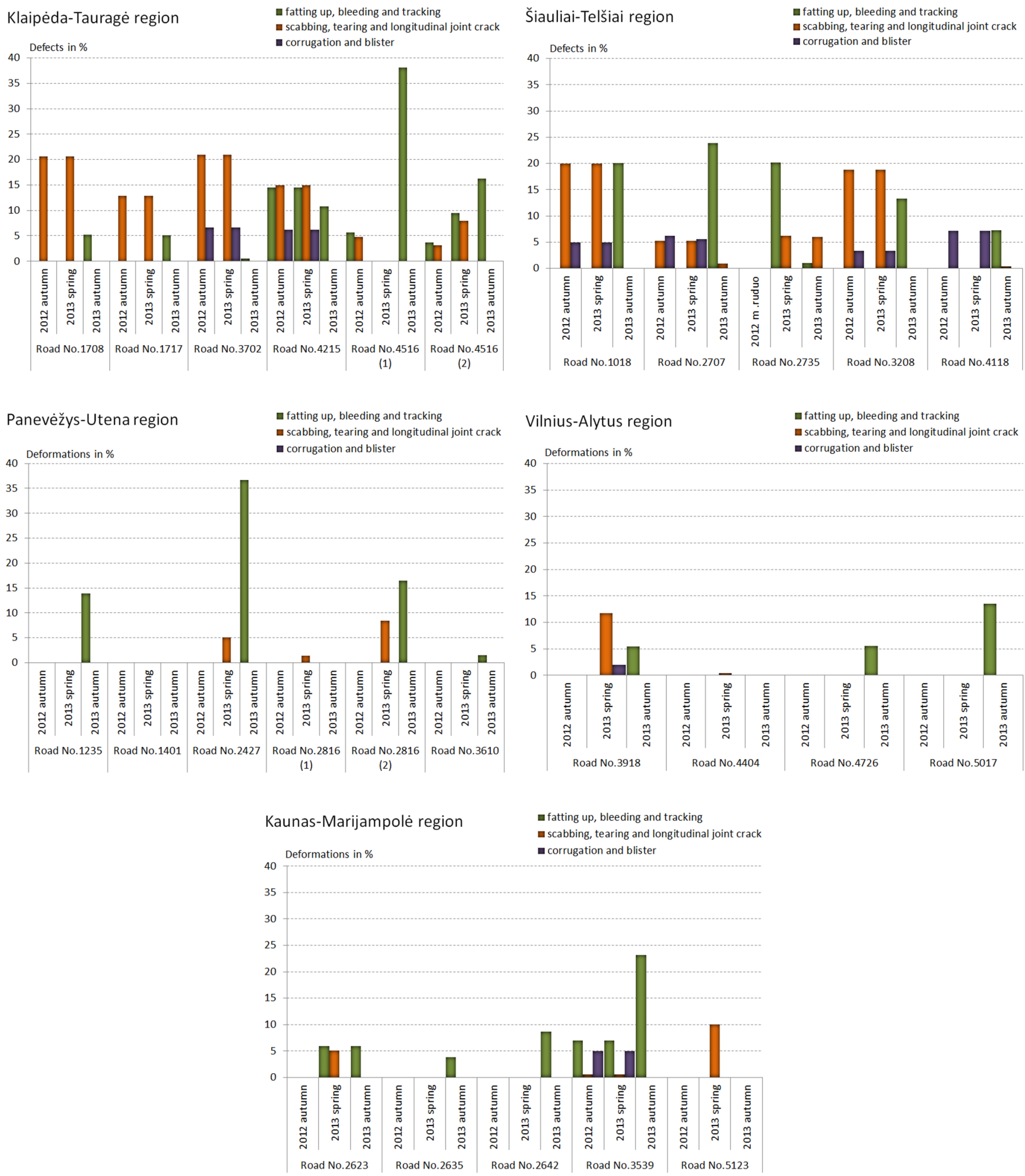

Fig. 3. Results of the qualitative visual assessment of the double Otta seal road sections 


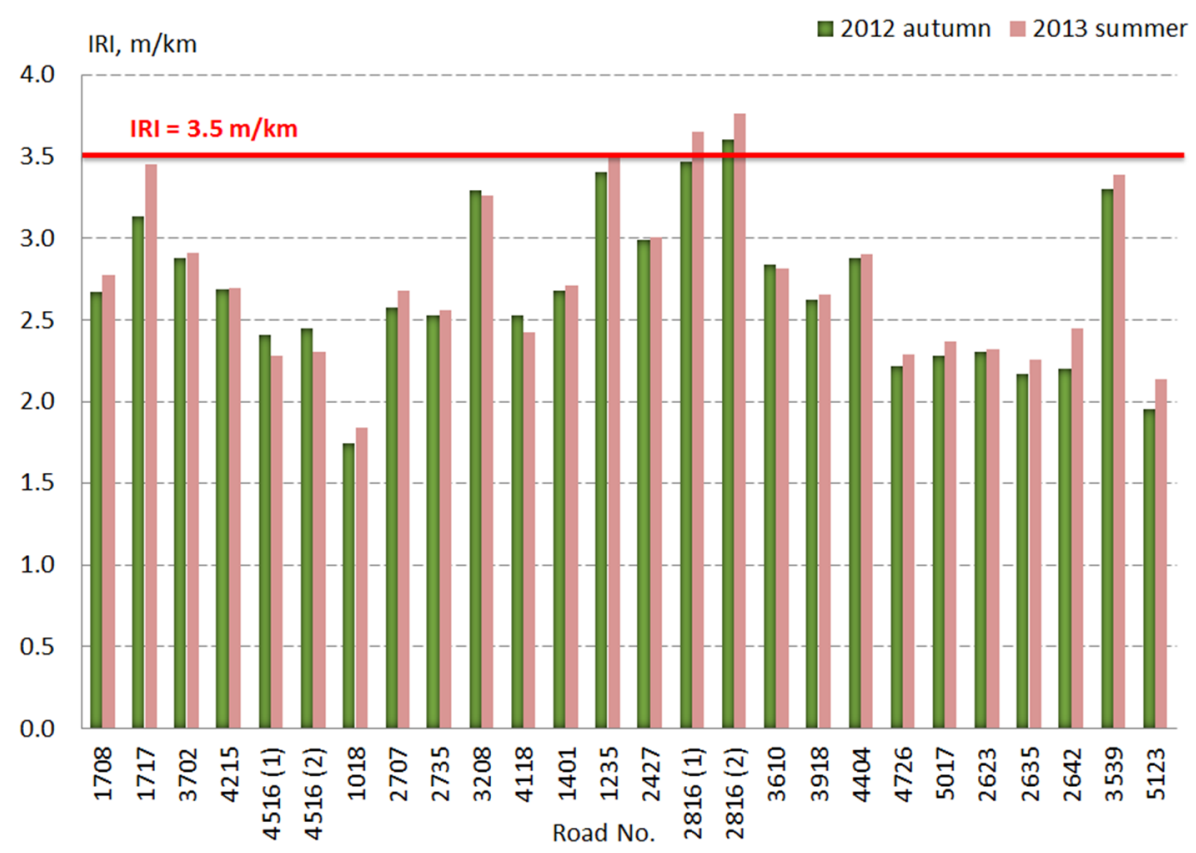

Fig. 4. IRI on the double Otta seal road sections

The roughness increased on most test road sections between November, 2012 and August, 2013, except several test road sections where the roughness decreased, i.e. IRI decreases from $2.41 \mathrm{~m} / \mathrm{km}$ to $2.28 \mathrm{~m} / \mathrm{km}$ on the road Nr. $4516(1)$ and from $2.45 \mathrm{~m} / \mathrm{km}$ to $2.31 \mathrm{~m} / \mathrm{km}$ on the road Nr. $4516(2)$ in Klaipeda-Taurage region and from $2.53 \mathrm{~m} / \mathrm{km}$ to $2.43 \mathrm{~m} / \mathrm{km}$ on the road Nr. 4118 in Šiauliai-Telšiai region (Fig. 4).

It was also determined that IRI met the requirement (IRI $<3.5 \mathrm{~m} / \mathrm{km}$ ) on almost all the test road sections. The exceptions were road Nr. 2816(1) in August, 2013 and road Nr. 2816(2) in November, 2012 and in August, 2013, where IRI >3.5 m/km (did not meet the requirement). These two test road sections are in the Panevėžys-Utena region.

\section{Conclusions and recommendations}

1. The double Otta seal surfacing was applied to the Lithuanian gravel roads with Annual Average Daily Traffic less than 500 vehicles per day based on the experience of foreign countries.

2. Most significant defects (fatting up, bleeding and tracking) were found in the test road sections after one year of operation. The causes were inappropriate aggregate of the double Otta seal and too high binder content and too soft (low viscosity) binder, as well as improperly carried out maintenance of the test road sections in summer. The causes of scabbing, tearing, and longitudinal joint crack, corrugation and blister were unqualified procedure of applying the double Otta seal. The cause of streaking was not enough binder and an uneven binder distribution within the nozzle beam.

3. 24 of the 26 test road sections with the double Otta seal met International Roughness Index requirement, i.e. was less than $3.5 \mathrm{~m} / \mathrm{km}$.

4. Based on the identification and causes of the defects found in Lithuanian test road sections with the double Otta seal, the following recommendations should be adopted:

- close attention should be given to the double Otta seal aggregate mixture preparation;

- the double Otta seal application procedure must closely followed;

- effective the double Otta seal road maintenance procedures must be implemented.

\section{References}

[1] Gintalas, V.; Čygas, D.; Žilionienè, D.; Puodžiukas, V. 2007. Longitudinal Profile of the Objects Included in the Gravel Roads Paving Program of Lithuania, The Baltic Journal of Road and Bridge Engineering 2(2): 53-59. ISSN 1822-427X print.

[2] Gintalas, V. 2010. Possibilities for the Improvement of the Quality of Design Solutions in the Gravel Road Reconstruction Projects. Doctoral Dissertation. VGTU. ISBN 978-9955-28-538-0.

[3] Overby, Ch. 1999. A Guide to the Use of Otta Seals. Norwegian Public Roads Administration. Oslo, 97 p. ISBN 82-9128-03-5.

[4] Overby, Ch.; Pinard, M. I. 2007. The Otta Seals Surfacing. An Economic and Practical Alternative to Traditional Bituminous Surface Treatments. 37 p.

[5] Overby, Ch.; Pinard, M. I. 2013. The Otta Seal Surfacing. A Practical and Economic Alternative to Traditional Bituminous Surface Treatments. Transportation Research Board 92th Annual Meeting, January 13-17, 2013. Washington D.C. 13 p.

[6] Overby, Ch. 1998. Otta Seal - a Durable and Cost-Effective Global Solution for Low-Volume Sealed Roads. 9th REAAA Conference, Wellington.

[7] Overby, Ch. 1982. Material and Pavement Design for Sealed Low Traffic Roads in Botswana. Norwegian Road Research Laboratory. Report no. 1042, Oslo.

[8] Overby, Ch. 1996. Sprayed Sealing Guide, Otta seals in Bangladesh. Norwegian Road Research Laboratory, Project N - 009A, Report No.1. Oslo. 